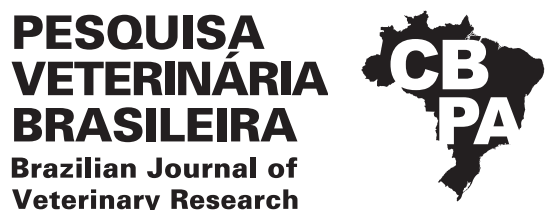

\title{
Macroscopic and microscopic morphology of the trachea and lungs of giant anteater ${\text { (Myrmecophaga tridactyla })^{1}}^{1}$
}

\author{
Evelyn Oliveira² ${ }^{\text {(D) }}$, Eduardo P. Nascente ${ }^{2}$, Leiny P. Oliveira² ${ }^{2}$ Jair M. Santiago Neto ${ }^{3}$, \\ Júlio C. Roquete ${ }^{4}$, Ana Paula I. Santin ${ }^{5}$ and Veridiana M.B.D. Moura ${ }^{5 *}$
}

\begin{abstract}
Oliveira E., Nascente E.P., Oliveira L.P., Santiago Neto J.M., Roquete J.C., Santin A.P.I. \& Moura V.M.B.D. 2020. Macroscopic and microscopic morphology of the trachea and lungs of giant anteater (Myrmecophaga tridactyla). Pesquisa Veterinária Brasileira 40(12):1054-1062. Setor de Patologia Animal, Departamento de Medicina Veterinária, Escola de Veterinária e Zootecnia, Universidade Federal de Goiás, Rodovia Goiânia Km 8, Campus Samambaia, Goiânia, G0 74001-970, Brazil. E-mail: vdmoura@hotmail.com

Giant anteater (Myrmecophaga tridactyla) is a wild mammal distributed in Central and South America; nowadays, it is classified as an endangered species. Research about the macroscopic and histomorphological aspects of its respiratory tract is scarce, and, sometimes, it limits the treatment provided to sick animals and impairs species preservation. Thus, the present study aims to describe the macroscopic and microscopic morphology of its lower respiratory tract, including trachea and lungs. To do so, 12 adult giant anteaters from "Centro de Triagem de Animais Silvestres de Goiânia" (CETAS-GO), Goiás State, Brazil, were used in the research after natural death or euthanasia. Three of these animals were used for macroscopic assessments; they were fixed in $10 \%$ buffered formalin and dissected. Trachea and lung tissue samples were collected from nine animals right after death and fixed in $10 \%$ buffered formalin for histomorphological analysis; they were processed, embedded in paraffin, and inked with hematoxylin-eosin (HE), periodic acid-Schiff (PAS), and Masson's trichrome. The macroscopic analysis showed that the trachea in this species is proportionally short and presents from 19 to 27 tracheal cartilages. The right lung presents four lobes and the left one, two. The microscopic analysis evidenced respiratory epithelium of the ciliated cylindrical pseudostratified type, without evident goblet cells in the mucosa layer of the trachea and bronchi. The pulmonary visceral pleura is thick, similar to other large domestic mammals complete septa extend from the pulmonary visceral pleura. In conclusion, the macroscopy and histomorphology of giant anteater's lower respiratory tract, represented by trachea and lungs, are similar to that of other domestic and wild mammals. Pulmonary histomorphology is mainly similar to that of pigs and ruminants: it has thick visceral pleura that emits complete septa of conjunctive tissue, which enable lobular parenchymal architecture.
\end{abstract}

INDEX TERMS: Morphology, trachea, lungs, giant anteater, Myrmecophaga tridactyla, anatomy, histology, respiratory tract, Xenarthras, wild animals.

RESUMO.- [Morfologia macroscópica e microscópica da traqueia e pulmões do tamanduá-bandeira (Myrmecophaga tridactyla).] 0 tamanduá-bandeira (Myrmecophaga tridactyla) é um mamífero silvestre com distribuição na América Central e

\footnotetext{
${ }^{1}$ Received on August 19, 2020.

Accepted for publication on November 2, 2020.

${ }^{2}$ Veterinarian, Graduate Program in Animal Science (PPGCA), Escola de Veterinária e Zootecnia (EVZ), Universidade Federal de Goiás (UFG), Rodovia Goiânia Km 8, Campus Samambaia, Goiânia, GO 74001-970, Brazil.

${ }^{3}$ Programa de Iniciação Científica e Graduação em Medicina Veterinária, Escola de Veterinária e Zootecnia (EVZ), Universidade Federal de Goiás (UFG), Rodovia Goiânia Km 8, Campus Samambaia, Goiânia, GO 74001-970, Brazil.
}

do Sul e, atualmente, encontra-se classificado como ameaçado de extinção. Pesquisas acerca dos aspectos macroscópicos e histomorfológicos do seu sistema respiratório são escassas, o que, por vezes, limita o tratamento e o manejo de eventuais

\footnotetext{
${ }^{4}$ Docente, Anatomia Animal, Departamento de Morfologia, Instituto de Ciências Biológicas (ICB), Universidade Federal de Goiás (UFG), Rodovia Goiânia Km 8, Campus Samambaia, Goiânia, GO 74001-970, Brazil.

${ }^{5}$ Docente, Setor de Patologia Animal, Departamento de Medicina Veterinária, Escola de Veterinária e Zootecnia (EVZ), Universidade Federal de Goiás (UFG), Rodovia Goiânia Km 8, Campus Samambaia, Goiânia, GO 74001-970, Brazil. *Corresponding author: vdmoura@hotmail.com
} 
animais doentes, bem como a preservação da espécie. Desse modo, o objetivo deste estudo foi descrever a morfologia macroscópica e microscópica do aparelho respiratório inferior do tamanduá-bandeira, incluindo traqueia e pulmões. Para tanto, foram utilizados 12 tamanduás-bandeiras adultos, provenientes do Centro de Triagem de Animais Silvestres de Goiânia (CETAS-GO), Goiás, Brasil, após morte natural ou eutanásia. Destes, três foram utilizados para o estudo macroscópico, sendo fixados em formalina tamponada a $10 \%$ e dissecados. Para a análise histomorfológica, amostras teciduais da traqueia e do pulmão foram colhidas de nove animais logo após o óbito, fixadas em formalina tamponada a $10 \%$, processadas, incluídas em parafina e coradas com hematoxilina e eosina (HE), ácido periódico-Schiff (PAS) e tricrômico de Masson. Â análise macroscópica notou-se que a traqueia é proporcionalmente curta, apresentando 19 a 27 cartilagens traqueais. 0 pulmão direito apresenta quatro lobos e o esquerdo dois. À análise microscópica foi constatado epitélio respiratório do tipo pseudoestratificado cilíndrico ciliado, sem células caliciformes evidentes na camada mucosa da traqueia e dos brônquios. A pleura visceral pulmonar é espessa, assim como nos grandes mamíferos domésticos, e, a partir desta, estendem-se septos completos. Conclui-se que a macroscopia e a histomorfologia do sistema respiratório inferior do tamanduá-bandeira, representado pela traqueia e pulmões, são semelhantes àquelas de outros mamíferos domésticos e silvestres. A histomorfologia pulmonar é especialmente semelhante à de suínos e ruminantes, com a pleura visceral espessa e emitindo septos completos de tecido conjuntivo, que conferem arquitetura parenquimal lobular.

TERMOS DE INDEXAÇÃO: Morfologia, macroscópica, traqueia, pulmões, tamanduá-bandeira, Myrmecophaga tridactyla, anatomia, animais silvestres, aparelho respiratório, histologia, Xenarthras.

\section{INTRODUCTION}

Giant anteater (Myrmecophaga tridactyla Linnaeus, 1758) is a wild mammal belonging to the super order Xenarthras, previously called Edentata, and order Pilosa featured by lack of teeth, dense coat, and strong claws in the hands (Chebez \& Cirignoli 2008, Miranda 2014). This species is natural to Central and South America in Brazil. It is widely distributed in almost all biomes, mainly in field and "Cerrado" regions (Wetzel 1985).

However, nowadays, it is considered an endangered species classified as vulnerable by the International Union for Conservation of Nature (IUCN) (Miranda et al. 2015). Factors such as deforestation, wildfires, and agricultural development reduce these animals' habitat and significantly affect countless wild species populations; giant anteaters are among the main mammals affected by wildfires and run overs (Cáceres et al. 2010, Superina et al. 2010).

Animals belonging to this species have anatomical and physiological specificities yet little explored, including those concerning the respiratory tract. The scarcity of studies focused on this topic negatively influences the clinical treatment provided to animals who are victims of accidents since the respiratory tract is responsible not only for air conduction and gas exchange but also for phonation, smell, and body temperature regulation, and excretion.
Thus, knowing the anatomy and physiology of this tract is of paramount importance for giant anteater's preservation and conservation (Lange et al. 2013), since previous studies have evidenced some anatomical features specific of this species. However, only the macroscopy and pulmonary segmentation of these animals were evidenced in these studies (Giraldi et al. 2017) therefore, there are some remaining gaps that still have to be approached in detail.

It is essential segmenting the organs composing the respiratory tract in order to simplify the understanding about its structures and functions; so, it is worth dividing it into upper (nasal cavity, pharynx and larynx) and lower (trachea and lungs) portions (López 2013). Airways, hematogenic pathway and direct extension are the main entrances to the respiratory tract. Airways and hematogenic pathway can become the viable access to toxins and microorganisms in case of accidents (López 2013, König \& Liebich 2016). Yet, the detailed description of organs and tracts makes it easier to understand this species' behavior and evolution (Giraldi et al. 2017) because it clarifies diagnostic and treatment questions, as well as favors species conservation (Sanders \& Feijó 2007).

Accordingly, the aim of the present study was to describe the macroscopic and histomorphological features of giant anteater's trachea and lungs in order to provide biological information about this species.

\section{MATERIALS AND METHODS}

The present study was approved by the Ethics Committee on Animal Use of "Universidade Federal de Goiás" (ECAU-UFG), under no. 010/2018, and authorized by "Sistema de Autorização e Informação em Biodiversidade" (SISBIO-IBAMA), no. 61810-1/2018. Twelve adult giant anteaters used in this study, being four females and eight males, weighing an average of $23 \mathrm{~kg}$, all from free-living, and captured or rescued by the "Centro de Triagem de Animais Silvestres de Goiânia”, Goiás (CETAS-GO). These nine died due to injuries caused by run overs, and three were euthanized due to multiple fractures and unlikely recovery.

Macroscopic analysis. Three animals were fixed in 10\% buffered formalin after death for further dissection in the lower respiratory tract's macroscopic analysis. The skin was removed, and buffered formalin intramuscular injections were administered in the whole extension of the corpses for fixation. Next, the corpses were immersed in vats filled with fixing solution for 72 hours. Subsequently, they were washed in running water for 12 hours and transferred to the supersaturated saline solution (30\%) to achieve conservation and handling throughout dissection.

The fasciae and muscles of the chest's ventral surface were moved for trachea and lungs access; next, the sternum was removed by disarticulating the costochondral junctions. The costal sternum railings were manually taken apart for photo-documentation with a digital camera (Camera Nikon D3300). Subsequently, the trachea dissected close to the mediastinum, and the whole set was removed from the larynx until mediastinum and lungs. These structures were subjected to microscopic analyses and the mesoscopic analysis of the trachea and lungs, tracheal cartilage count, and lung lobe identification through interlobular fissures.

Microscopic analysis. Nine animals were subjected to necroscopic examination after death to collect samples for the microscopic analysis. From the right lung were collected, two samples of the middle and accessory lobes and three samples were obtained of the 
cranial and caudal lobes. From the trachea, samples were obtained of the cranial, middle, and caudal segments. All samples were fixed in $10 \%$ buffered formalin for 48 hours, processed in increasing ethyl alcohol solutions, clarified in xylol, embedded in paraffin, and cut to $5 \mu \mathrm{m}$. Cuts were unbend over the histologic slide and inked with hematoxylin and eosin (HE), periodic acid-Schiff (PAS), and Masson's trichrome, based on Tolosa et al. (2003). Trachea fragments were descaled in 8\% formic acid and hydrochloric acid solution for 72 hours before the histological processing.

The histological cuts were analyzed in a bright-field optical microscope (Leica DM $4000^{\circledR}$ ), and a system provided the digital photomicrographs to capture images (Leica Application Site - LAS) coupled to the microscope. The different strata composing the trachea were described, and the structure of both the parenchyma and pulmonary stroma, including the bronchial tree components.

\section{RESULTS}

\section{Trachea}

In macroscopic terms, the trachea is a flexible tubular organ that goes from the caudal portion of the cricoid laryngeal cartilage, by the sixth cervical vertebra, until the bronchial bifurcation (carina), by the fifth thoracic vertebra; it is the origin of the principal, right and left bronchi. The ventral portion and the trachea sides were formed by incompletecartilage-ring-shaped entangled by fibroelastic tissue (the annular ligaments). The dorsal portion was formed by muscle tissue (tracheal muscle), more flexible, which bonds the rings' edges. The cervical portion of the trachea was short since the larynx in this species is close to the thorax entrance (Fig.1A). In this study's animals, the size of the trachea ranged from 8.0 to $10.8 \mathrm{~cm}$, with an average tracheal size of $9.24 \mathrm{~cm}$. The tracheal lumen diameter varied from 1.45 to $1.55 \mathrm{~cm}$, and the average of $1.5 \mathrm{~cm}$ in diameter. The number of tracheal cartilages ranged from 19 to 27, with an average of 22 cartilages (Fig.1B).

Three different tunics were observed in the histomorphological analysis applied to the trachea: mucosa, submucosa, and adventitious. Mucosa surface was coated by the ciliated cylindrical pseudostratified epithelium (Fig.2A); without evidence of goblet cells throughout the whole extension of the respiratory epithelium (Fig.2B). The lamina propria and the submucosa were deep in the respiratory epithelium; however, the difference between these two structures was not established. They presented loose conjunctive tissue with collagen fibers, serous glands, tubuloacinous mucous

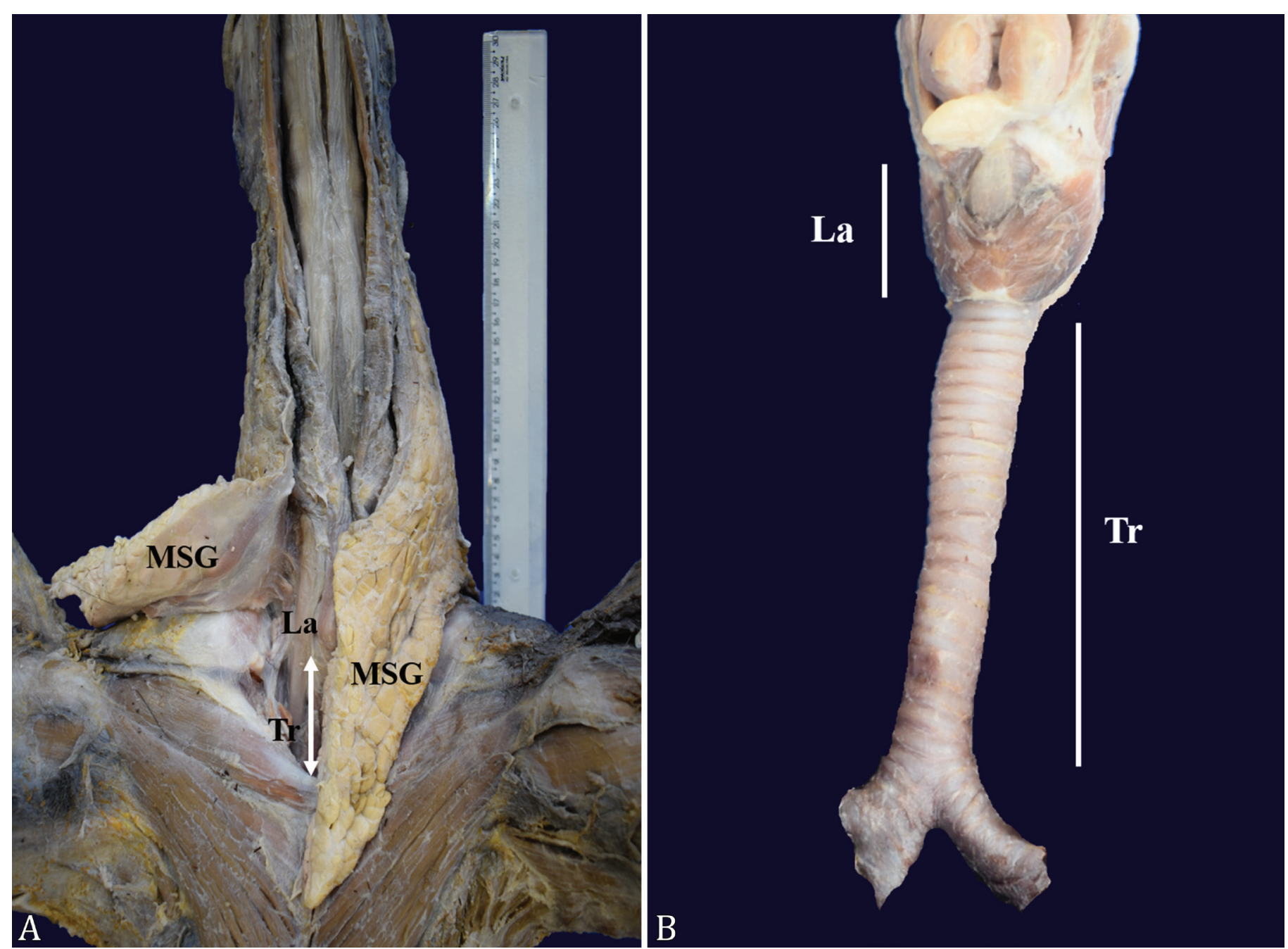

Fig.1. (A) Ventral face of neck and thorax (B) and ventral view of the trachea and larynx of the giant anteater (Myrmecophaga tridactyla). (A) Mandibular salivary glands (MSG), Larynx (La) and the cervical part of the trachea (Tr). (B) Larynx (La) and trachea (Tr). 
membranes (at different sizes). Sometimes, the glandular duct would open to the trachea (Fig.2C) and blood vessels (at different calipers) (Fig.2D).
C-shaped incomplete cartilage ring deeper inside; it was composed of hyaline cartilage coated by perichondrium, the edges were free and had an opening in them. The hyaline

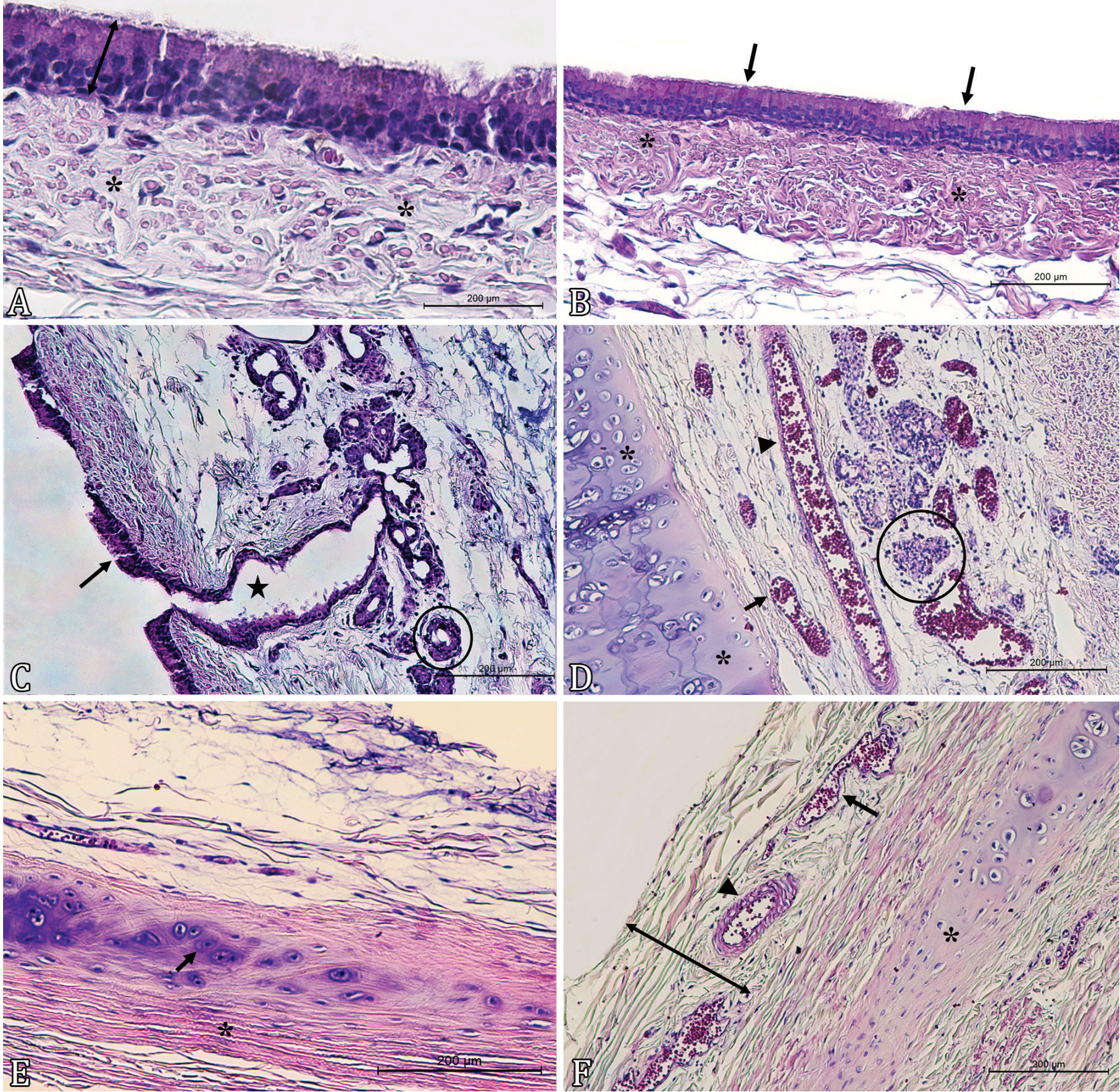

Fig.2. Photomicrographs of giant anteaters' trachea (Myrmecophaga tridactyla. (A) Cylindrical pseudo-stratified epithelium (double arrow) and lamina propria submucosa (asterisks), HE, bar $=200 \mu \mathrm{m}$. (B) Cylindrical pseudo-stratified epithelium (arrows), without evidence of goblet cells, PAS, bar $=200 \mu \mathrm{m}$. (C) Cylindrical pseudo-stratified epithelium (arrow) and lamina propria-submucosa composed of loose conjunctive tissue with collagen fibers, serous glands (circle) at different sizes, with glandular duct open to the trachea (star), $\mathrm{HE}$, bar $=200 \mu \mathrm{m}$. (D) Arterioles (arrowhead), venules (arrow) and serous glands (circle) distributed on in the submucosal layer, close to the hyaline cartilage (asterisk), HE, bar $=200 \mu \mathrm{m}$. (E) Hyaline cartilage (arrow) and smooth muscle (asterisk) interspersed, HE, bar $=200 \mu \mathrm{m}$. (F) Adventitia layer (double arrow) composed of loose connective tissue with collagen fibers, arterioles (arrowhead) and venules (arrow) dispersed in its whole extension, close to the hyaline cartilage (asterisk), HE, bar $=200 \mu \mathrm{m}$. 
cartilage and smooth muscle were interspersed (Fig.2E), which was featured by spindle fibers in parallel, at the cross-sectional position, this muscle filled the gaps between tracheal cartilage. There was an adventitious tunic heading outside (Fig.2F); the tunic was composed of loose connective tissue, collagen fibers, and arterial and venous vessels (at different calibers).

\section{Lungs}

The right lung of giant anteater was bigger and split in four lobes: cranial, middle, caudal and accessory. The cranial lobe was sub-divided into the cranial and caudal parts. The left lung, in its turn, had two lobes called 'cranial' and 'caudal' (Fig.3A,B). They were both covered by the pleura, which was also covered by a thick layer of subserous tissue - the interlobular septa spread out from this tissue.

In microscopic terms, the histological lung samples (at the magnitude of $10 \mathrm{x}$ ) showed pulmonary parenchyma of the typical lacy aspect. The pulmonary histological structure could be divided into visceral pleura, bronchi, bronchioles, alveolar ducts, and alveolar sacs. The visceral pleura was relatively thick and composed of the mesothelium in its external portion; the mesothelium, in its turn, was composed of simple squamous epithelium. There were loose conjunctive tissue and blood vessels of different calipers deeper inside (Fig.4A). There were complete septa composed of loose conjunctive tissue from the pleura (Fig.4B) and extending to inside the organ; it separated the pulmonary parenchyma into lobes (Fig.4C). These septa also had blood vessels (at different calipers) throughout their full extension.

Bronchi were large (Fig.4D) and coated by ciliated cylindrical pseudostratified epithelium, with a moderate amount of goblet cells (Fig.4E); epithelium height was proportional to the caliper of the assessed bronchus. Adjacent lymphoid tissue was featured by the accumulation of lymphocytes close to the respiratory epithelium, known as bronchus-associated lymphoid tissue (BALT). The division between the lamina propria and the submucosa was evident, and both were composed of conjunctive tissue rich in collagen fibers. The mucosa's muscle layer had fibers of smooth muscle distributed in an oblique or circular form, as well as scarce plates of hyaline cartilage (Fig.4F), serous glands, and small arterial and venous vessels.

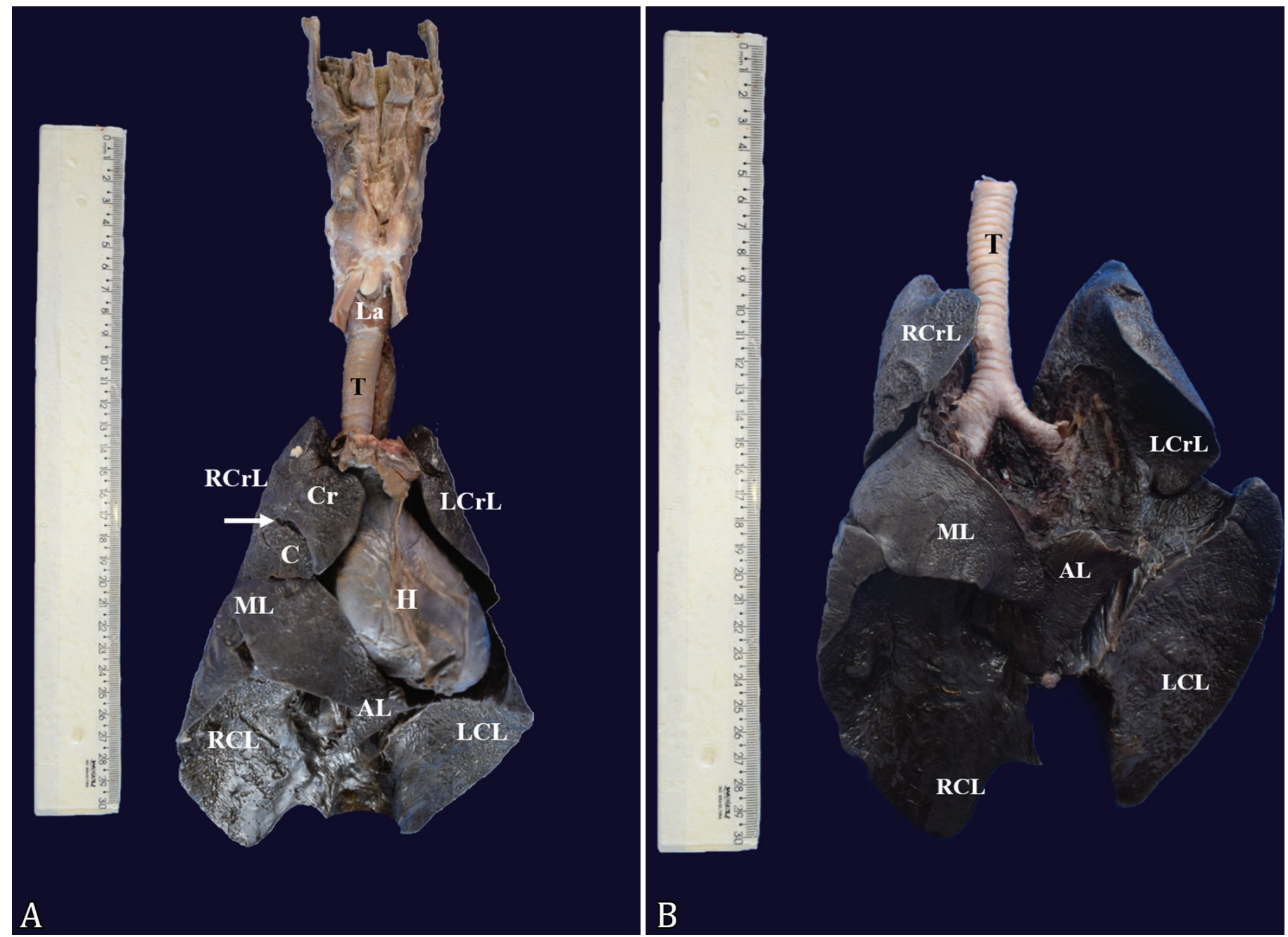

Fig.3. (A) Ventral face of the lower respiratory tract of giant anteater (Myrmecophaga tridactyla). (B) The same structures described in Figure A, with the absence of the heart to show the accessory lobe. Larynx (La), trachea (T), right cranial lobe (RCrL), cranial part of the right cranial lobe (Cr), caudal part of the right cranial lobe (C), interlobular fissure (arrow), middle lobe (ML), accessory lobe (AL), right caudal lobe (RCL), Heart (H), left cranial lobe (LCrL) and left caudal lobe (LCL). 

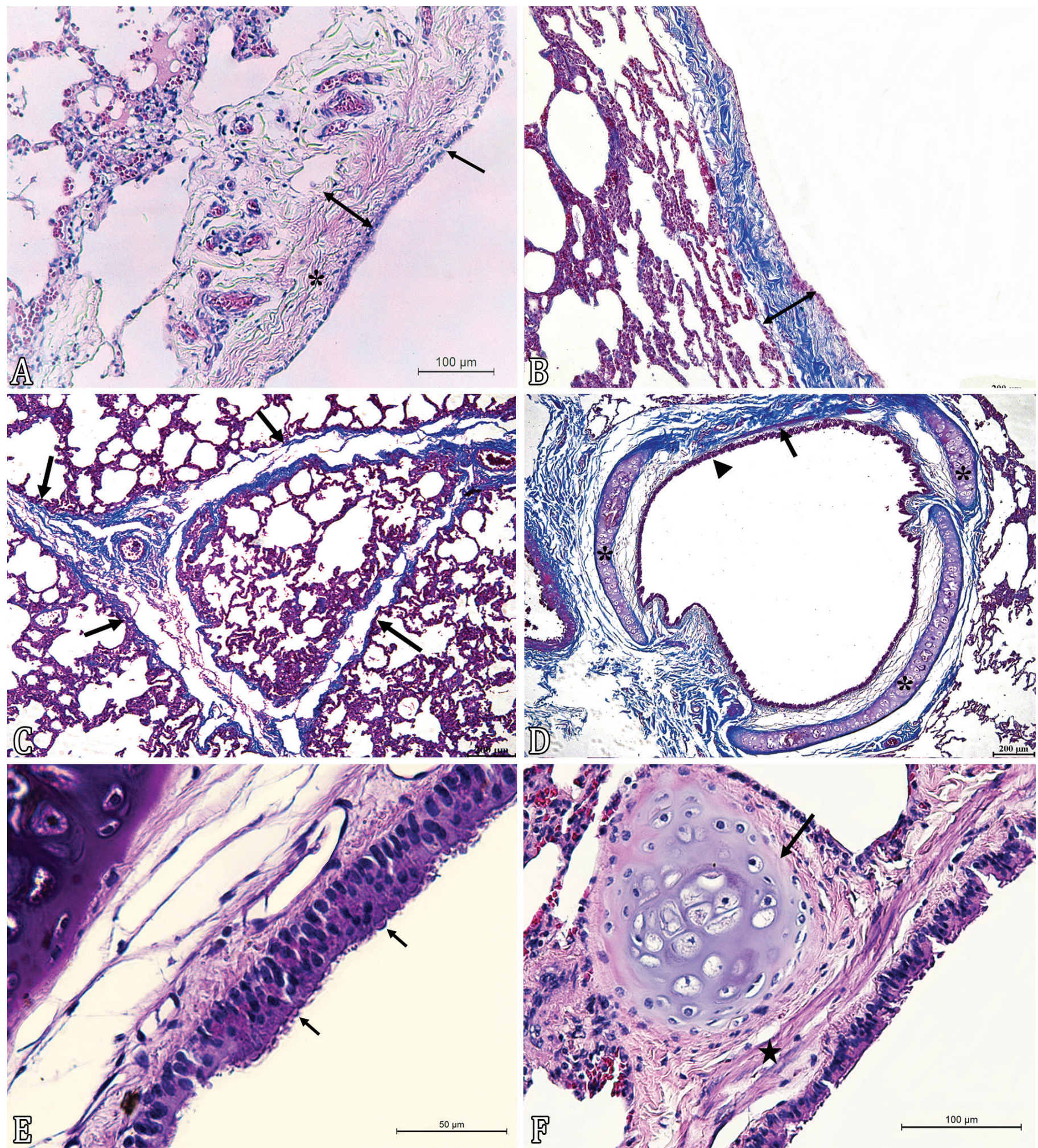

Fig.4. Photomicrographs of the lung of giant anteater (Myrmecophaga tridactyla). (A) Thick pulmonary pleura (double arrow), formed by simple pavement epithelium (arrow) and loose connective tissue (asterisk). HE, bar = 100 $\mu$ m. (B) Pulmonary pleura (double arrow) with blue collagen highlighted. Masson's trichrome, bar $=200 \mu \mathrm{m}$. (C) Blue connective tissue septa (arrows), separating the lung parenchyma into lobes. Masson's trichrome, bar $=200 \mu \mathrm{m}$. (D) Pulmonary bronchus with ciliated cylindrical pseudostratified epithelium (arrowhead), lamina propria formed by connective tissue followed by muscular layer of the mucosa, with smooth muscle (arrow). Typical submucosa and hyaline cartilage plaques (asterisk) adjacent to connective tissue. Masson's Trichrome, bar $=200 \mu \mathrm{m}$. (E) Bronchus showing ciliated cylindrical pseudo-stratified epithelium without evidence of goblet cells. PAS, bar $=50 \mu \mathrm{m}$. (F) Hyaline cartilage plaque (arrow) typical of the pulmonary bronchus. Deeply to the epithelium, its own submucosal lamina with emphasis on the muscular layer of the mucosa of circular orientation (star), HE, bar $=100 \mu \mathrm{m}$. 
Bronchioles were smaller than (Fig.5A) and different from the bronchi, mainly because they did not present hyaline cartilage plates on the submucosa. The mucosa was coated by simple epithelium (at different heights); it could be cylindrical or cubic and present lashes or not. The lamina propria and the submucosa were in a deeper layer; therefore, it was not possible to set a partition between them; they were relatively thin and composed of loose conjunctive tissue, small amounts of arterial vessels, smaller venous vessels, and by few areas with smooth muscle fibers distributed in circular orientation (Fig.5B). There was lymphoid tissue in the bronchioles (Fig.5C), which was featured by the accumulation of lymphocytes close to the bronchiolar epithelium region.

Alveolar sacks did not present smooth muscle on the wall, which was formed by alveoli. These alveoli were covered by a thin layer of simple squamous epithelium, which formed the alveolar wall (Fig.5D). The alveoli were separated by interalveolar septa composed of conjunctive and capillary tissue in its inner side and by the alveoli's simple squamous epithelium in its external side.

\section{DISCUSSION}

The lower respiratory tract is featured by tubes that widespread - the so-called "tracheobronchial airways," and reach the alveolar gas exchange apparatus (Eurell \& Frappier 2006). The trachea is the longest of these tubes; it goes from the larynx's cricoid cartilage to the bifurcation in the thoracic cavity (König \& Liebich 2016). However, the length of this organ in giant anteater representatives was shorter than in species such as ruminants and horses, which show from 48 to 60 tracheal cartilages;
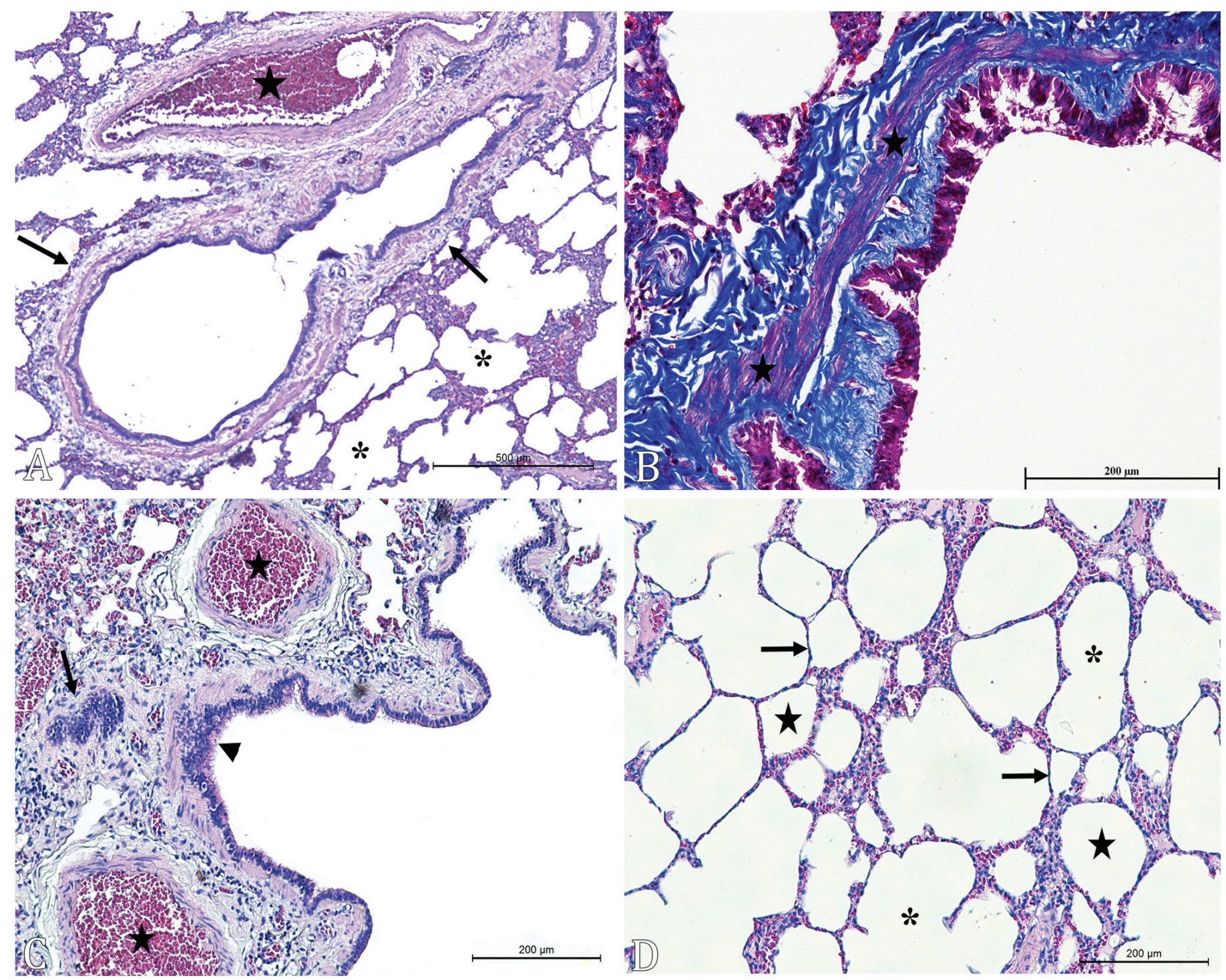

Fig.5. Photomicrographs of bronchioles and pulmonary alveoli of giant anteater (Myrmecophaga tridactyla). (A) Pulmonary bronchioles (arrow) characterized by the absence of hyaline cartilage plaques, with artery (star), alveolar sacs (asterisks) and adjacent alveoli, $\mathrm{HE}$, bar $=500 \mu \mathrm{m}$. (B) Muscle layer, eosinophilic color (star), in circular orientation in the bronchiolar wall, Masson's Trichrome, bar = $200 \mu \mathrm{m}$. (C) Lymphoid tissue (arrow) characterized by the accumulation of lymphocytes close to the region of the bronchiolar epithelium (arrowhead) and arterioles (stars), HE, bar $=200 \mu \mathrm{m}$. (D) Alveolar sacs (asterisks) and pulmonary alveoli (stars) covered by a thin layer of squamous epithelial cells (arrow), forming the alveolar wall. HE, bar $=200 \mu \mathrm{m}$. 
dogs, who have 42 to 46 cartilages; cats, who have 38 to 43 cartilages (König \& Liebich 2016), capybaras have from 35 to 46 cartilages (Moreto et al. 2017) and 34 cartilages in the coatis, on average (Oliveira et al. 2011). On average, giant anteaters have 22 tracheal cartilages; this number was close to the one reported for skunks, which present 25 cartilages, on average (Bertassoli et al. 2013). The fact that the larynx is more caudal in giant anteaters contributes to their shorter trachea, making the cervical portion of the trachea exiguous. This is relevant knowledge in emergencies or anesthetic procedures since inhalation anesthesia in this species is more complex given a hard time intubating these animals. Tracheostomy would be a plausible alternative, as reported by Brainard et al. (2008); however, this procedure requires proper knowledge about the region's topographic anatomy. Although this segment is short, it is also covered by the mandibular salivary gland.

The lower respiratory tract is featured by tubes that widespread, the so-called "tracheobronchial airways", and reach the alveolar gas exchange apparatus (Eurell \& Frappier 2006). The trachea is the longest of these tubes; it goes from the larynx's cricoid cartilage to the bifurcation in the thoracic cavity (König \& Liebich 2016). However, the length of this organ in giant anteater representatives was shorter than in species such as ruminants and horses, which show from 48 to 60 tracheal cartilages; dogs, who have 42 to 46 cartilages; cats, who have 38 to 43 cartilages (König \& Liebich 2016), capybaras have from 35 to 46 cartilages (Moreto et al. 2017) and 34 cartilages in the coatis, on average (Oliveira et al. 2011). On average, giant anteaters have 22 tracheal cartilages; this number was close to the one reported for skunks, which present 25 cartilages, on average (Bertassoli et al. 2013). The fact that the larynx is more caudal in giant anteaters contributes to their shorter trachea, making the cervical portion of the trachea exiguous. This is relevant knowledge in emergencies or anesthetic procedures since inhalation anesthesia in this species is more complicated given a hard time intubating these animals. Tracheostomy would be a plausible alternative, as reported by Brainard et al. (2008); however, this procedure requires proper knowledge about the region's topographic anatomy. Although this segment is short, it is also covered by the mandibular salivary gland. In the present study, tracheal mucosa was coated by the respiratory epithelium and had serous glands, similar to the description made for domestic (Banks 1993) and wild species (Moussa \& Hassan 2015, Rocha et al. 2017, Mario et al. 2018). The tracheal muscle was inserted in the tracheal cartilage's internal face, similar to horses, pigs, and ruminants, but different from carnivores and humans, whose muscle fixation occurs on the external surface of the tracheal cartilages (Bacha \& Bacha 2012, König \& Liebich 2016).

Overall, pulmonary lobe subdivisions are similar in different species of mammals. The right lung is formed by the cranial, middle, caudal and accessory lobes, and the left one by the cranial and caudal lobes. The same features are observed in dogs, cats, pigs (König \& Liebich 2016), capybaras (Moreto et al. 2017), coatis (Oliveira et al. 2011), and giant anteaters. However, different from these animals, and similar to cattle, goats, and sheep, the cranial lobe of the right lung in Myrmecophaga tridactyla is divided into cranial and caudal parts, as described by Giraldi et al. (2017).

Lungs can be split into intrapulmonary airways (bronchi and bronchioles), gas exchange areas (ducts and alveolar sacs and alveoli), and pleura (Eurell \& Frappier 2006). Giant anteaters' pleura forms a serous membrane that covers the lungs; it is formed by mesothelium on its surface and, deeper inside, by loose conjunctive tissue and blood vessels, as reported for domestic animals (Banks 1993). However, different from dogs and cats, who present thin pleura, animals in the present study showed thick pleura, as described for large mammals such as cattle, horses, and pigs (Eurell \& Frappier 2006, Bacha \& Bacha 2012, König \& Liebich 2016).

Besides being thicker, the pleura tissue in giant anteaters is continuous, septa form lobes; similar to pigs, ruminants (Bacha \& Bacha 2012), and ringed seal (Phoca hispida), septa are complete. This pattern is different from that observed in horses, who show incomplete septa of conjunctive tissue, which features this species' little lobulated lungs (Eurell \& Frappier 2006).

In domestic animals and humans, bronchi are histologically similar to the trachea; however, they present thinner extracts. The mucosa is coated with typical respiratory epithelium; lamina propria and submucosa are composed of loose conjunctive tissue, glands, smooth muscle, blood vessels, hyaline cartilage, and, sometimes, accumulated lymphoid tissue (Eurell \& Frappier 2006, Junqueira \& Carneiro 2013). All these features were also observed in pulmonary tissue collected from giant anteaters in the present research. The assessed bronchioles presented simpler morphology; cartilage and glands, similar to domestic animals (Bacha \& Bacha 2012), human beings (Junqueira \& Carneiro 2013), and to animals such as quaint (Monodelphis domestica) (Cope et al. 2012) and red fox (Moussa \& Hassan 2015), the absence of these structures is the primary way of differentiating bronchioles from the bronchi.

Pulmonary structures composing the gas exchange apparatus are similar to those described for domestic (Banks 1993) and wild animals (Smodlaka et al. 2006, Oliveira et al. 2011, Cope et al. 2012, Moussa \& Hassan 2015, Rocha et al. 2017). However, different from what was reported for such animals, there were no alveolar macrophages in giant anteaters. However, the microscopic evaluation under hematoxylin and eosin ink did not exclude the likelihood of finding these cells in the species mentioned above. Therefore, immunophenotyping tests would be an alternative to confirm or not the presence of these cells in giant anteaters' pulmonary gas exchange apparatus.

\section{CONCLUSIONS}

Giant anteaters' trachea presents 22 tracheal cartilages, on average. The trachea is smaller and more caudal than in other species of domestic and wild mammals. Its cervical portion is tiny and coated by salivary glands. The histomorphology of the lower portion of the respiratory tract in giant anteaters is equal to that of other domestic and wild mammals.

The pulmonary histomorphology is quite similar to that of pigs and ruminants. The visceral pleura is thick and emits complete septa formed by conjunctive tissue, enabling lobular parenchymal architecture.

Acknowledgments.- Evelyn de Oliveira thanks the "Conselho Nacional de Desenvolvimento Científico e Tecnológico" (CNPq) for granting scholarship. We thank the "Centro de Triagem de Animais Silvestres" (CETAS) of the State of Goiás, Brazil, for providing institutional support.

Conflict of interest statement.- The authors declare that there are no conflicts of interest. 


\section{REFERENCES}

Bacha W.J. \& Bacha L.M. 2012. Color Atlas of Veterinary Histology. 3rd ed. Wiley-Blackwell, London, p.195-210.

Banks W.J. 1993. Applied Veterinary Histology. 3rd ed. Mosby, St. Louis, p.390-407.

Bertassoli B.M., Santos A.C., Oliveira F.D., Oliveira D.M., Assis-Neto A.C. \& Carvalho A.F. 2013. Morfologia da laringe e traqueia de gambás (Didelphis sp.). Ciênc. Anim. Bras. 14(2):222-229. <https://dx.doi.org/10.5216/cab. v14i2.17044>

Brainard B.M., Newton A., Hinshaw K.C. \& Klide A.M. 2008. Tracheostomy in the Giant Anteater (Myrmecophaga tridactyla. J. Zoo Wildl. Med. 39(4):655658. <https://dx.doi.org/10.1638/2007-0124.1><PMid:19110713>

Cáceres N.C., Hannibal W., Freitas D.R., Silva E.L., Roman C. \& Casella J. 2010. Mammal occurrence and roadkill in two adjacent ecoregions (Atlantic Forest and Cerrado) in south-western Brazil. J. Zoologia, Curitiba, 27(5):709-717. <https://dx.doi.org/10.1590/S1984-46702010000500007>

Chebez J. \& Cirignoli Y. 2008. Mamíferos, p.31-40. In: Chebez J.C. (Ed.), Los que se Van, Fauna Argentina Amenazada. Vol.3. Albatros, Argentina.

Cope L.A., Henry R.W. \& Reed Jr R.B. 2012. Microscopic anatomy of the lower respiratory tract of the Grey Short-Tailed Opossum (Monodelphis domestica). Anat. Histol. Embryol. 41(2):96-105. <https://dx.doi. org/10.1111/j.1439-0264.2011.01107.x><PMid:21919952>

Eurell J.A. \& Frappier B.L. 2006. Dellmann's Textbook of Veterinary Histology. 6th ed. Blackwell Publishing, Iowa, p.153-169.

Giraldi A.C.C., Aires L.P.N., Rodrigues R.F., Cruvinel T.M.A. \& Melo A.P.F. 2017. Anatomia e segmentação pulmonar de tamanduá-bandeira (Myrmecophaga tridactyla - Linnaeus, 1758) de vida livre. Arq. Bras. Med. Vet. Zootec. 69(1):22-28. <https://dx.doi.org/10.1590/1678-4162-9197>

Junqueira L.C. \& Carneiro J. 2013. Histologia Básica, Texto e Atlas. $12^{\mathrm{a}}$ ed. Guanabara Koogan, Rio de Janeiro, p.676-712.

König H.E. \& Liebich H.G. 2016. Anatomia dos Animais Domésticos, Texto e Atlas Colorido. $6^{\mathrm{a}}$ ed. Artmed, Porto Alegre, p.377-398.

Lange R., Lang A., Allgayer M., Albuquerque I., Rossi Júnior J. \& Chiesorin Neto L. 2013. Das práticas em zoológico à especialização dos dias atuais. Revta CFMV 19(59):13-15.

López A. 2013. Sistema respiratório, mediastino e pleuras, p.1183-1407. In: Zachary J.F. \& McGavin M.D. (Eds), Bases da Patologia em Veterinária. $5^{\mathrm{a}}$ ed. Elsevier Brasil, Rio de Janeiro.

Mario L.C., Borghesi J., Hayashi R.G., Favaron P.O., Rodrigues M.N., Carvalho R.C. \& Miglino M.A. 2018. Morphology of the Oligoryzomys nigripes respiratory system. Anat. Histol. Embryol. 47(4):364-371.<https://dx.doi.org/10.1111/ ahe.12363><PMid:29869399>

Miranda F.R. 2014. Cingulata (tatus) e Pilosa (preguiças e tamanduás), p.707722. In: Cubas Z.S., Silva J.C.R. \& Catão-Dias J.L. (Eds), Tratado de Animais Selvagens Medicina Veterinária. $2^{a}$ ed. Roca, São Paulo.

Miranda F.R., Chiarello A.G., Rohe F., Braga F.G., Mourão G.M. \& Miranda G.H.B. 2015. Avaliação do risco de extinção de Myrmecophaga tridactyla Linnaeus, 1758 no Brasil. Avaliação do Risco de Extinção de Xenartros Brasileiros, Instituto Chico Mendes de Conservação da Biodiversidade, ICMBio, Brasília, p.89-105.

Moreto A.O., Oliveira F.D., Bertassoli B.M. \& Neto A.C.A. 2017. Morfologia comparada do aparelho respiratório de capivaras (Hydrochoerus hydrochoeris). Pesq. Vet. Bras. 37(3):269-277. <https://dx.doi.org/10.1590/ s0100-736x2017000300011>

Moussa E.A. \& Hassan S.A. 2015. Histology and scanning electron microscopy of the lower respiratory tract in the adult Red Fox (Vulpes vulpes). Int. J. Morphol. 33(1):267-274. <https://dx.doi.org/10.4067/S071795022015000100042>

Oliveira V.C., Souza A.F., Santos A.C., Bertassoli B.M., Rosa R.A., Carvalho A.F., Martins J.F.P. \& Mançanares C.A.F. 2011. Estudo morfológico do sistema respiratório de quati (Nasua nasua). Biotemas 25(1):81-92. <https:// dx.doi.org/10.5007/2175-7925.2012v25n1p81>

Rocha M.P., Nunes A.P., Minello L.F., Cruz L.A.X., Albano A.P.N. \& Mondadori R.G. 2017. Histological description of Cerdocyon thous (Linnaeus, 1766) respiratory system. Pesq. Vet. Bras. 37(5):531-535. <https://dx.doi. org/10.1590/s0100-736x2017000500018>

Sanders A. \& Feijó A.G.S. 2007. Uma reflexão sobre animais selvagens cativos em zoológicos na sociedade atual. Revta SORBI 1(4):1-10.

Smodlaka H., Reed R.B. \& Henry R.W. 2006. Microscopic anatomy of the ringed seal (Phoca hispida) lower respiratory tract. Anat. Histol. Embryol. 35(1):35-41. <https://dx.doi.org/10.1111/j.1439-0264.2005.00635.x> <PMid:16433671>

Superina M., Miranda F.R. \& Abba A.M. 2010. The 2010 anteater red list assessment. Edentata 11(2):96-114. <https://dx.doi.org/10.5537/020.011.0201>

Tolosa E.M.C., Rodrigues C.J., Behmer O.A. \& Freitas Neto A.G. 2003. Manual de técnicas para histologia: normal e patológica. Manole, São Paulo. 341p.

Wetzel R.M. 1985. The identification and distribution of recent Xenarthra (Edentata), p.5-21. In: Montgomery G. (Ed.), The Evolution and Ecology of Armadillos, Sloths, and Vermilinguas. Smithsonian Institution Press, Washington, D.C. 